\title{
KONFLIK MAHASISWA TIMUR DI KOTA MALANG \\ (Studi Kasus pada Mahasiswa Timur di Kota Malang)
}

\author{
Kresna Abdi Parela ${ }^{1}$, Winin Maulidya Saffanah ${ }^{2}$, Khoirul Anwar ${ }^{3}$ \\ 1. Ikip Budi Utomo Malang \\ krisparela@yahoo.com
}

\begin{abstract}
ABSTRAK
Konflik antar kelompok merupakan salah satu hal yang kerap terjadi dalam masyarakat. Perbedaan identitas serta nilai yang dianut dapat membuat terjadinya gesekan antar dua kelompok yang berada di masyarakat tak terkecuali pada mahasiswa dengan asal berbeda yang ada di kota Malang. Penelitian ini sendiri lebih berfokus pada mahasiswa Indonesia Timur karena kerap terjadi gesekan baik dengan sesama kelompok mahasiswa maupun dengan masyarakat sekitar lingkungan tempat tinggal mereka.Penelitian ini sendiri akan membahas secara khusus mengenai efek dari konflik ini dan melihat hingga ke akar penyebab terjadinya hal tersebut. Perbedaan lingkungan yang dialami mahasiswa asal Indonesia Timur serta eratnya hubungan mereka yang berasal dari daerah sama membuat mereka menjadi satu kelompok yang solid terutama ketika terjadi pertentangan dengan kelompok yang lain. Penelitian ini sendiri menggunakan pendekatan kualitatif dan narasumber dipilih dengan cara snow ball sampling. Data dari penelitian ini didapat melalui observasi, wawancara, serta dokumentasi. Data yang didapat dari mahasiswa kemudian akan dielaborasi dengan berbagai dokumen yang didapat baik dari media maupun kepolisian. Berdasar berbagai data tersebut kemudian dilihat penyebab dari terjadinya konflik serta pemecahan yang dilakukan dalam mengatasi masalah tersebut.
\end{abstract}

Kata kunci: peta konflik, konflik, mahasiswa, Indonesia timur

\begin{abstract}
Intergroup conflict is something that often occur in society. Differences of identity and values adopted could occurence the clash between two group that exist in society. This thing is also happen in students from different origins in Malang. This research is focusing in students from East Indonesia since they often involved in the friction both with fellow student groups or with communities near their neighborhood. Spesifically, this study will discuss about effect dan see it through the roots of this conflict. The enviromental diffirences experienced by students from Eastern Indonesia and their close relationships with friends from the same region make them a solid group especially when there is conflict with other groups. This research uses qualitative approach and informan is chosen by snow ball sampling. Data from this research is collected through observation, interview, and documentation. Data obtained from students will be elaborated with various documents obtained from both media and police.Based on these various data then would be seen cause of the occurrence of conflicts and solutions that have been done in overcoming the problem.
\end{abstract}

Keywords: conflict map, conflict, student, east Indonesia

2. Ikip Budi Utomo Malang

wininwinin@gmail.com

3. Ikip Budi Utomo Malang

khoirulanwar@gmail.com 


\section{PENDAHULUAN}

Sebagai kota pendidikan dengan empat perguruan tinggi negeri dan puluhan perguruan tinggi swasta, Kota Malang merupakan tempat berkumpulnya sejumlah pelajar dan mahasiswa dari sejumlah daerah. Hal ini jugalah yang membuat tingginya interaksi antar mahasiswa dan pelajar dari sejumlah daerah di Indonesia. Interaksi ini kadang terjadi dalam mimbar pendidikan di kampus namun bisa juga terjadi dalam interaksi kehidupan sehari-hari di luar kampus. Salah satu Mahasiswa pendatang di Kota Malang yang jumlahnya cukup banyak dan tersebar di berbagai Kampus adalah Mahasiswa asal Indonesia Timur. Mahasiswa asal Indonesia Timur datang ke Malang selain untuk belajar, mereka juga bersosialisasi dan berinteraksi serta membawa budaya yang berasal dari daerah masing-masing. Interaksi yang terjadi tidak hanya melibatkan mahasiswa pendatang asal Indonesia Timur dengan warga Kota Malang tapi juga antara Mahasiswa pendatang asal Indonesia Timur yang berbeda daerah

Interaksi antar mahasiswa ini juga tak selamanya berlangsung dengan damai dan penuh nuansa akademis layaknya mahasiswa. Beberapa kali terjadi friksi antara mahasiswa karena memang kepribadian dan budaya asal yang berbeda antara mereka. Walaupun seringkali masalah ini berasal dari masalah pribadi, namun pada ujungnya tak jarang terjadi keterlibatan secara lebih luas bahkan menyangkutpautkan sesama mahasiswa dari wilayah tertentu. Konflik pribadi yang meluas dan menjadi masalah kelompok ini kadang mengakibatkan friksi yang tak jarang meluas dan melibatkan benturan secara fisik. Hal ini lah yang kadang menimbulkan prasangka bahwa kelompok tertentu yang biasanya memiliki kesamaan identitas dan daerah asal mejadi dianggap penuh kekerasan dan tercoreng di mata masyarakat. Lebih parah lagi, kadang konflik ini juga tak usai dan terus diturunkan kepada kelompok mahasiswa dengan usia yang lebih muda dan tidak terlibat sejak awal konflik.

Sejumlah konflik antar mahasiswa di Kota Malang tak hanya sekali, tercatat pada Maret 2015 ratusan mahasiswa asal Sumba dipulangkan ke daerah asalnya untuk mengurangi gesekan yang lebih besar lagi. Pada November 2015, seorang mahasiswa NTT tewas setelah dikeroyok sesama mahasiswa NTT. Upaya penyelesaian konflik antar mahasiswa juga telah dilakukan berbagai pihak, bahkan gubernur NTT dan Pemkot Kota Malang sempat melakukan audensi. Terjadinya konflik ini memang tak lepas dari persinggungan yang terjadi dalam kehidupan sehari-hari baik antarindividu maupun antar manusia. Alo Liliweri (2005:256) mengatakan bahwa potensi konflik ini terjadi manakala terjadi kontak antar manusia. Semakin intens sebuah kontak antar manusia terjadi maka semakin besar potensi terjadinya konflik ini. 
Dengan kondisi mahasiswa dengan latar belakang yang berbeda tinggal dan bersekolah di suatu tempat yang sama, sangat mungkin terjadinya interaksi ini. Dengan latar belakang yang berbeda dan kepentingan yang berbeda pula, besar kemungkinan terjadinya konflik antar mereka. Hal ini dapat ditambah pula dengan adanya faktor gengsi atau persaingan antar kelompok yang dapat membuat interaksi ini berlangsung secara panas dan dapat mengakibatkan berbagai konflik antara mereka.

Berdasarkan pemaparan di atas, peneliti tertarik untuk melakukan kajian tentang Dinamika Hubungan Antar Mahasiswa Pendatang Asal Timur di Kota Malang karena peneliti melihat hubungan antar Mahasiswa Pendatang asal Timur ini tidak selalu berjalan mulus bahkan sering terjadi konflik. Peneliti ingin menganalisis faktor-faktor apa saja yang menyebabkan terjadinya konflik antar mahasiswa pendatang asal Timur di Kota Malang kemudian memetakannya menjadi sebuah Peta Konflik dan diharapkan bisa menjadi solusi untuk mengatasi konflik yang di antara mahasiswa pendatang asal Indonesia Timur.

\section{METODE PENELITIAN}

\section{Desain Penelitian}

Penelitian ini menggunakan pendekatan kualitatif dengan jenis penelitian deskriptif yaitu penelitian yang berusaha mendeskripsikan dan menginterpretasikan sesuatu, misalnya kondisi atau hubungan yang ada, pendapat yang berkembang, proses yang sedang berlangsung, akibat atau efek yang terjadi, atau tentang kecendrungan yang tengah berlangsung. Dalam hal ini peneliti akan meneliti tentang Peta Konflik Mahasiswa Timur Di Kota Malang (Studi Kasus Pada Mahasiswa Timur di Kota Malang). Tempat dan Lokasi Penelitian ini adalah di Kota Malang yaitu di Kampus, Polres dan tempat tinggal Mahasiswa Pendatang Asal Timur dengan durasi waktu 6 bulan yang terhitung mulai April 2018 sampai September 2018. Subjek dalam penelitian ini adalah Mahasiswa Pendatang Asal Indonesia Timur yang pernah terlibat konflik secara langsung, Mahasiswa asli Malang dan Mahasiswa asal Indonesia Timur yang mengetahui dan mempunyai informasi tentang konflik yang terjadi, Warga Kota Malang, Pihak Kepolisian baik dari Polres maupun Polsek yang memiliki data konflik mahasiswa pendatang asal Timur di Kota Malang serta telah ditetapkan menggunakan Metode Purposive Sampling, dimana subjek yang akan diteliti telah dipilih dan ditetapkan sesuai karakteristik penelitian. Teknik Pengumpulan Data dalam Penelitian ini menggunakan metode wawancara terarah (Guided Interview) di mana peneliti menanyakan hal-hal yang sudah dipersiapkan sebelumnya kepada para Narasumber yang telah ditetapkan dan dipilih menggunakan Teknik Purposive Sampling. Teknik Analisa data dalam penelitian ini menggunakan Metode Miles dan Hubberman, dimana data akan dikumpulkan dengan menggunakan teknik wawancara terarah kepada narasumber, 
kemudian data hasil wawancara yang berbentuk transkrip diolah, dalam hal ini hasil wawancara dari narasumber yang tidak terpakai akan direduksi. Tahap berikutnya adalah data akan disajikan dalam bentuk tabel yang mencakup tahun terjadinya konflik, penyebab, korban, penyelesaian dan akan ditarik kesimpulannya sehingga akan ditemukan penyebab terjadinya konflik, daerah dan kampus asal mahasiswa yang berkonflik dan dari data-data tersebut akan dibuat sebuah pemetaan.

\section{KERANGKA TEORI/KONSEP}

\section{Perspektif Teori Struktural Konflik}

Teori ini dipaparkan dalam rangka memahami dinamika yang terjadi di dalam masyarakat. Di dalam realitas masyarakat, konflik sebagai hal yang harus ada dan kehadirannya tidak dapat ditawar-tawar lagi. Adanya perbedaan kekuasaan dapat dipastikan menjadi sumber konflik dalam sebuah sistem sosial, terutama masyarakat yang kompleks dan heterogen. Tidak hanya itu, Sumber daya yang langka (terutama sumber daya ekonomi) di dalam masyarakat akan membangkitkan kompetisi di antara pelaku ekonomi yang memperebutkannya dan bukan mustahil berujung pada pertikaian akibat persoalan distribusi sumber daya tersebut yang tidak pernah merata. Kelompok-kelompok kepentingan yang berbeda dalam sistem sosial akan saling mengejar tujuan yang berbeda dan saling bersaing. Kondisi semacam ini, dalam banyak kasus kerap menyebabkan terjadinya konflik terbuka, sebagaimana dinyatakan oleh Locknwood dalam Jonathan Turner 1978 (dalam Wirawan 2012 :60), bahwa kekuatankekuatan yang saling bersaing dalam mengejar kepentingannya masing-masing akan melahirkan mekanisme ketidakteraturan social (Social Disorder).

Teori konflik berbeda dengan teori struktural fungsional yang mengacu pada keajegan dan keteraturan serta dalam memahami masyarakat. Jika kalangan fungsionalis melihat adanya saling ketergantungan dan kesatuan dalam masyarakat, maka kalangan penganut teori konflik justru melihat masyarakat merupakan arena di mana satu kelompok dengan yang lain saling bertarung untuk memperebutkan "power" dan mengontrol bahkan melakukan penekanan bagi saingan-saingan mereka (Wirawan 2012:61). Jika kalangan fungsionalis melihat hukum atau undang-undang sebagai sarana untuk meningkatkan integrasi sosial, maka para penganut teori konflik melihat undang-undang itu tidak lain merupakan cara yang digunakan untuk menegakkan dan memperkukuh suatu ketentuan yang menguntungkan kelompok tertentu di atas pengorbanan kelompok lainnya. 
Kresna Abdi Parela, Winin Maulidya Saffanah, Khairul Anwar

\section{PEMBAHASAN}

Sebagai sebuah kota pendidikan yang ditinggali oleh mahasiswa dari berbagai macam daerah di Indonesia, konflik kerap kali terjadi di kota Malang. Baik antara mahasiswa dengan daerah asal yang berbeda atau antara mahasiswa dengan penduduk lokal, konflik ini kerap kali terjadi baik dalam skala yang kecil maupun cukup besar.

Ketika dilakukan pencarian di peramban Google dengan kata kunci "tawuran mahasiswa asal Indonesia timur di Malang akan ditemukan 155.000 hasil pencarian. Sedangkan pencarian dengan kata kunci "konflik mahasiswa asal Indonesia timur di Malang" malah menghasilkan jumlah yang lebih banyak lagi yaitu 431.000 hasil pencarian.

Berdasar data Polresta Malang, pada tahun 2014 sendiri berdasar kasus yang ditangani oleh Polresta terdapat empat kasus yang melibatkan mahasiswa Indonesia Timur. Dua kasus yang terjadi merupakan penganiayaan sedangkan dua kasus lainnya merupakan tawuran.

Kasus penganiyaan pertama melibatkan seorang mahasiswa Universitas Negeri Malang sebagai korban. AN (20 tahun) mahasiswa asal Kepulauan Sangihe menjadi korban pengeroyokan. Pada saat itu dia menggeber kendaraannya di jalan sambil memaki sejumlah orang. AN sendiri diduga mabuk pada saat itu dan membuat pelaku pengeroyokan tersinggung. Pelaku tercatat sebagai anggota TNI AD dan menyerahkan diri kepada polisi.

Kasus kedua juga merupakan kasus penganiayaan, hanya saja pada kasus kedua ini korban penganiayaan merupakan masyarakat lokal dan pelaku merupakan mahasiswa asal Indonesia Timur. Kasus ini terjadi di wilayah Purwantoro dan melibatkan RB (25 tahun) asal Ende yang menyabetkan parang kepada MS (54) warga di sekitar tempat kejadian perkara. RB sendiri diduga sedang mabuk pada kala itu dan warga sekitar yang resah memanggil polisi untuk mengamankan pelaku. MS yang tengah bernegosiasi dengan RB malah diserang oleh pelaku di bagian tangan dan mengalami luka sayatan. Polisi sendiri yang saat itu juga hadir di tempat kejadian harus melepaskan enam kali tembakan peringatan dan kemudian terpaksa melumpuhkan pelaku dengan empat tembakan ke arah kaki sebelum pelaku berhasil diamankan.

Kasus ketiga merupakan tawuran antara kelompok mahasiswa asal Kalimatan melawan kelompok mahasiswa asal Sumba di Universitas Kanjuruhan Malang. Tawuran ini sendiri terjadi pada Jumat 23 Mei 2014 pukul 22.30. Asal masalah tawuran ini sendiri terjadi sehari sebelumnya ketika ada senggolan anatara mahasiswa asal Sumba dengan mahasiswa asal Kalimantan saat latihan tari. Pada saat itu terjadi pemukulan yang kemudian berujung pada 
tawuran yang terjadi sehari sebelumnya. Kasus ini sendiri juga melibatkan kelompok mahasiswa asal Ambon.

Masalah ini membuat polisi harus menernukan satu kompi Brimob serta satu pleton Dalmas Polres Malang Kota untuk pengamanan wisuda yang dilaksanakan sehari setelah tawuran. Ketiga kelompok mahasiswa bersama polisi kemudian membuat kesepakatan untuk mencegah konflik yang lebih besar lagi.

Kasus tawuran kedua terjadi antara kelompok mahasiswa Sumba dengan kelompok mahasiswa Ambon. Kasus ini terjadi di Tlogomas dan diawali oleh hampir terjadinya pemukulan terhadap saudari dari mahasiswa kelompok Ambon. Mahasiswa dengan inisial P yang mencoba melerai pemukulan ini malah jadi sasaran pemukulan hingga mengalami luka lebam. Kelompok mahasiswa Ambon lainnya yang tidak terima ini kemudian menghubungi teman-teman mereka hingga mengakibatkan hampir terjadi tawuran besar. Masalah ini sendiri diduga diawali oleh pelaku yang sedang dipengaruhi oleh minuman beralkohol.

Pada kasus ini terjadi aksi saling lempar batu serta serangan menggunakan senjara tajam. Sempat terjadi kejar-kejaran di jalan raya serta penyerbuan pada salah satu rumah kos. Sejumlah kos-kosan rusak pada kejadian tersebut serta seorang mahasiswa asal Sumba menjadi korban pembacokan. Polisi sendiri menurunkan satuan Brimob dari Ampeldento serta personel dari Polsek Lowokwaru, Blimbing, dan Kedungkandang. Untuk meredahkan aksi tawuran tembakan peringatan sebanyak tiga sampai empat kali diberikan oleh polisi. Sekitar 20 mahasiswa diamankan pada tawuran tersebut dan selama beberapa hari polisi masih melakukan penjagaan, khawatir terjadinya bentrok susulan.

Pada tahun 2015, berdasar data dari Polresta Malang hanya terdapat satu konflik yang melibatkan mahasiswa asal Indonesia Timur yang tercatat. Namun kasus ini sendiri tergolong cukup besar karena berupa tawuran antara kelompok mahasiswa asal Ambon dengan kelompok mahasiswa asal Sumba. Sama seperti pada kasus tawuran di Tlogomas, tawuran yang terjadi di Universitas Kanjuruhan ini awalnya terjadi karena masalah individu dan dipicu oleh minuman keras.

Masalah ini terjadi pada 20 November 2015 ketika salah seorang mahasiswa asal Ambon hendak mengambil uang ke ATM. Saat itu dia mendapat panggilan dari salah seorang mahasiswa kelompok Sumba yang berada di dalam kampus. Miskomunikasi yang terjadi terutama karena dipengaruhi minuman keras membuat salah satu mahasiswa asal Sumba ini marah dan melempar batu. 
Sempat terjadi negosiasi dan pertemuan dari dua kelompok yang bertikai hingga akhirnya masalah sempat dianggap selesai. Namun rupanya kelompok mahasiswa Sumba pada malam hari selanjutnya datang membawa parang dan mendatangi tempat kos mahasiswa asal Ambon sehingga membuat konflik ini membesar. Kelompok Sumba sendiri menyebut bahwa masalah ini dipicu oleh makian dari kelompok Ambon yang sedang melintas mengendarai mobil. Tidak ada korban jiwa dari kejadian ini hanya saja terdapat beberapa rumah yang mengalami pengrusakan ketika terjadi tawuran.

Pada tahun 2016 juga terjadi tawuran antar kelompok mahasiswa asal Indonesia Timur yaitu antara kelompok mahasiswa Ambon dan kelompok mahasiswa Sumba. Keributan kali ini terjadi di depan Universitas Wisnu Wardhana Malang. Masalah ini sendiri terjadi pada 19 Maret 2016 dan berawal dari kegiatan di dalam kampus.

Saat ini dilangsungkan pelantikan Ketua Komunitas Mahasiswa Maluku Universitas Wisnu Wardhana yang dihadiri oleh komunitas suku Ambon se-Malang. Pada saat pelantikan datang empat orang dari kelompok Sumba untuk turut menghadiri namun karena pakaian yang digunakan kurang rapi sehingga mereka diminta untuk menggunakan pakaian yang lebih sopan. Kelompok tersebut akhirnya kembali lagi dengan pakaian lebih sopan namun empat orang membawa senjata tajam dalam bentuk parang dan pisau. Keempat orang tersebut akhirnya dibawa ke tempat parkir untuk menghindari masalah lebih lanjut.

Setelah itu, terdapat pelemparan ke dalam kampus oleh kelompok Sumba dengan menggunakan batu dan kayu. Hal ini memicu keributan lebih lanjut dan membuat salah satu mahasiswa dari kelompok Ambon terkena sabetan parang.

Sejumlah kasus tersebut merupakan kasus yang tercatat oleh Polresta Malang pada 2014-2016. Pada 2017 sendiri tidak ada kasus yang melibatkan mahasiswa asal Indonesia Timur yang tercatat oleh Polresta Malang. Pada tahun 2018 terdapat satu kasus tawuran yang melibatkan mahasiswa asal Papua dengan penduduk lokal di daerah Dinoyo.

Berbeda dengan kasus sebelumnya yang murni bentrokan karena permasalahan sepele, kasus pada tahun 2018 ini memiliki dimensi politik. Konflik ini bermula dari rencana pemutaran film sejarah Papua Barat yang bakal diselenggarakan di di Sekretariat IPMAPAPARA (Ikatan Pelajar Mahasiswa Papua Paniai Raya) Jl. MT. Hariyono Gang 8C / 986 Kota Malang. Warga sekitar yang keberatan akhirnya membubarkan pemutaran film tersebut.

Kelompok mahasiswa yang tidak terima dengan pembubaran tersebut papua keluar dari kontrakan dan berjalan ke arah jalan raya Jl. Mayjen Panjaitan dan melakukan long march menuju Mako Polres Malang Kota. Mahasiswa yang melakukan long march tersebut sambil 
berteriak Papua Merdeka berkali-kali sehingga membuat warga jengkal dan melakukan pelemparan batu. Mahaiswa juga membalas pelemparan batu ini namun aksi ini dapat dilerai dengan cepat karena adanya anggota polisi yang turut mendampingi.

Berdasar data di atas diketahui bahwa pada 2014 terdapat empat kasus melibatkan mahasiswa asal Indonesia Timur yang ditangani oleh Polresta Malang. Pada 2015 dan 2016 sendiri terdapat masing-masing satu kasus konflik mahasiswa asal Indonesia Timur yang ditangani Polresta Malang. Pada tahun 2017 tidak ada konflik yang melibatkan mahasiswa asal Indonesia Timur di Kota Malang. Sedangkan hingga Juli 2018, telah terdapat satu kasus yang melibatkan mahasiswa asal Indonesia Timur. Total sejak 2014-2018, terdapat tujuh kasus di Polresta Malang yang melibatkan mahasiswa asal Indonesia Timur.

Tabel 1. Jumlah Konflik Mahasiswa Asal Indonesia Timur yang Ditangani Polresta Malang

\begin{tabular}{cc}
\hline \hline Tahun & Jumlah Kasus \\
\hline 2014 & 4 \\
\hline 2015 & 1 \\
\hline 2016 & 1 \\
\hline 2017 & 0 \\
\hline 2018 & 1
\end{tabular}

Sumber: Olahan Peneliti, 2018.

Ditinjau dari jenis konflik yang dialami, sebagian besar kasus yang terjadi merupakan tawuran antar kelompok. Sedangkan konflik lain yang terjadi berupa penganiayaan serta sebuah konflik lagi memiliki dimensi politik dan berupa pertengkaran dengan warga. Terdapat empat kasus tawuran yang terjadi selama lima tahun di kota Malang. Sedangkan dua kasus lagi merupakan penganiayaan yang melibatkan mahasiswa asal Indonesia Timur masing-masing sebagai korban maupun pelaku. Satu kasus lain merupakan masalah dengan warga sekitar dan melibatkan dimensi politik di dalamnya.

Tabel 2. Jenis Konflik yang Dialami Mahasiswa Asal Indonesia Timur 2014-2018

\begin{tabular}{cc}
\hline \hline Jenis Konflik & Jumlah Kasus \\
\hline Tawuran & 4 \\
\hline Penganiayaan & 2 \\
\hline Masalah politik & 1
\end{tabular}

Sumber: Olahan Peneliti, 2018. 
Konflik yang terjadi pada mahasiswa asal Indonesia Timur ini sebagian besar melibatkan adanya minuman keras. Kondisi sedang mabuk ini menyebabkan terjadinya gesekan antar individu yang berujung penganiayaan atau juga membesar menjadi tawuran antar kelompok. Walau begitu tak semua kasus tawuran juga bermula dari kondisi mabuk dan miskomunikasi ini, dua kasus tawuran diawali oleh kondisi mabuk hingga menyebabkan salah satu kelompok tersinggung sedangkan dua kasus yang lain berawal dari masalah yang terjadi di dalam kampus. Pada kasus penganiayaan, kedua konflik yang terjadi murni disebabkan karena pengaruh minuman keras. Satu kasus yang lain terjadi karena masalah politik dari mahasiswa asal Indonesia Timur.

Tabel 3. Penyebab Konflik yang Dialami Mahasiswa Asal Indonesia Timur 2014-2018

\begin{tabular}{cc}
\hline \hline Penyebab Konflik & Jumlah Kasus \\
\hline Minuman Keras & 4 \\
\hline Masalah dalam kampus & 2 \\
\hline Masalah politik & 1 \\
\hline
\end{tabular}

Sumber: Olahan Peneliti, 2018.

Berdasar sebaran lokasi dari konflik sendiri, seluruh kasus berada di wilayah yang cukup dekat dengan Perguruan Tinggi. Beberapa kasus bahkan berada tidak hanya di wilayah sekitar namun di dalam Perguruan Tinggi itu sendiri. Jika dibagi berdasarkan wilayah atau kecamatan di kota Malang, konflik ini terjadi pada empat dari lima sektor kepolisian yang ada di Kota Malang. Pembagian wilayah ini sendiri tidak berdasarkan dari pembagian wilayah Pemkot Malang namun berdasarkan pembagian sektoral wilayah kepolisian di Malang. Pemilihan penggunaan pembagian berdasar sektor ini sendiri adalah karena sebagian kasus ini memiliki dimensi masalah hukum sehingga lebih tepat melihatnya dari pembagian sektor ala polisi dibanding dari sudut administratif kecamatan kota.

Di wilayah Lowokwaru, terdapat tiga kasus yang terjadi dan merupakan wilayah yang paling banyak mengalami konflik mahasiswa asal Indonesia Timur. Pada wilayah Sukun terdapat dua konflik yang terjadi dan keduanya berada di tempat yang sama. Sedangkan di Blimbing dan Kedungkandang, masing-masing terdapat satu kasus yang terjadi.

Tabel 4. Lokasi Konflik yang Dialami Mahasiswa Asal Indonesia Timur 2014-2018

\begin{tabular}{cc}
\hline \hline Lokasi Konflik & Jumlah Kasus \\
\hline Lowokwaru & 3 \\
\hline Sukun & 2 \\
\hline
\end{tabular}

35 | SLSIOGLLBAL : Jurnal Pemikiran dan Penelitian Sasiologi, Vol. 3, No. I, Desember 2018 


\begin{tabular}{cl}
\hline \hline Blimbing & 1 \\
\hline Kedungkandang & 1
\end{tabular}

Sumber: Olahan Peneliti, 2018.

Selanjutnya, pada empat kasus tawuran yang terjadi diketahui bahwa bentrokan antar kelompok mahasiswa ini cukup rentan terjadi. Beberapa kelompok mahasiswa walaupun berada di lokasi yang berbeda bahkan cenderung lebih rentan dan sering mengalami konflik berupa tawuran dibanding kelompok lainnya. Pada seluruh kasus tawuran yang terjadi, seluruhnya melibatkan kelompok mahasiswa asal Sumba dan Ambon. Hanya pada satu kasus di tahun 2014, selain melibatkan mahasiswa asal dua kelompok tersebut terdapat juga kelompok mahasiswa asal Kalimantan.

Tabel 5. Kelompok Mahasiswa Yang Terlibat Tawuran di Kota Malang 2014-2018

\begin{tabular}{cc}
\hline \hline Kelompok Mahasiswa yang Terlibat & Jumlah Kasus \\
\hline Sumba & 4 \\
\hline Ambon & 4 \\
\hline Kalimantan & 1 \\
\hline
\end{tabular}

Sumber: Olahan Peneliti, 2018.

Kasus-kasus yang disebut di atas merupakan konflik yang ditangani oleh Polresta Malang, data di atas belum mencakup konflik-konflik lebih kecil yang tak tercatat dan dalam lingkup yang lebih kecil. Konflik-konflik dalam cakupan yang lebih kecil dan antar personil juga kerap terjadi dan dapat berakhir cepat tanpa melibatkan polisi turun tangan dan dapat diselesaikan dengan jalan musyawarah.

Pada sebagian besar konflik yang terjadi pada mahasiswa asal indonesia Timur tersebut, masalah kerap kali dipicu karena kondisi salah seorang atau suatu kelompok yang mabuk dan dalam pengaruh minuman keras. Hal inilah yang berujung pada masalah yang akhirnya terjadi dan bahkan pada beberapa kasus masalah individu yang dipicu oleh kondisi mabuk ini kemudian menjadi tawuran antar dua kelompok suku.

Konflik sendiri secara teori merupakan salah satu bagian dari interaksi sosial. Secara proses, konflik sendiri berada pada tahapan keempat pada sebuah interaksi sosial. Liliweri (2005:129) menjelaskan bahwa dalam sebuat interaksi sosial terdapat proses yang terdiri atas (1) pertukaran sosial; (2) kerja sama; (3) persaingan; dan (4) konflik. 
Pada dua kelompok mahasiswa yang saling berkonflik sendiri, biasanya awalnya interaksi terjadi di dalam kampus baik dalam perkuliahan atau kegiatan lain. Selanjutnya hubungan ini meningkat menjadi sebuah kerja sama yang kemudian menjadi persaingan. Persaingan ini sendiri kemudian akan menjadi konflik baik antara individu atau dengan mengatasnamakan kelompok yang diidentifikasi dekat dengan identitas mereka.

Merujuk pada pengertian dari Liliweri (2005:146), konflik merupakan suatu bentuk pertentangan alamiah yang dihasilkan oleh individu atau kelompok yang berbeda etnik (suku bangsa, ras, agama, golongan), karena di antara mereka memiliki perbedaan dalam sikap, kepercayaan, nilai, atau kebutuhan. Sering kali konflik itu dimulai dengan hubungan pertentangan antara dua atau lebih etnik (individu atau kelompok) yang memiliki, atau merasa memiliki, sasaran-sasaran tertentu namun diliputi pemikiran, perasaan, atau perbuatan yang tidak sejalan.

Menurut Isre (2003:5-6) akar konflik itu adalah suatu tingkat marjinalisasi sosial atau penderitaan sosial yang tidak bias ditolerir dalam perebutan sumber daya dan kekuasaan. Solidaritas kelompok terbentuk karena upaya memperjuangkan nilai-nilai, status sosial, kekuasaan dan berbagai sumberdaya yang langka dengan cara melemahkan, merusak atau menghancurkan pihak lawan.

Tawuran yang terjadi pada kelompok mahasiswa ini sebagian sebenarnya terjadi karena konflik atau masalah individu antar kelompok. Konflik individu ini kemudian menjadi komunal dalam bentuk tawuran karena adanya rasa solidaritas yang disebabkan karena persamaan identitas. Identitas yang sama ini sendiri berada dalam bentuk kelompok etnik, walau begitu kesamaan identitas ini sendiri sesungguhnya dapat dipilih oleh seorang individu tersebut. Sen (2016:33) menjelaskan bahwa sesungguhnya seseorang tercakup dalam berbagai kelompok yang berbeda, seorang individu dapat memutuskan apakah suatu kelompok pertalian tersebut bermakna penting atau tidak baginya. Dalam kasus ini, kesamaan identitas etnik menjadi hal yang dianggap penting sehingga mendorong masalah individu menjadi masalah kelompok yang berujung pada tawuran.

Permasalahan ini sendiri dapat terjadi karena adanya kemungkinan dari identitas kedua kelompok mahasiswa yang dalam hal ini mahasiswa asal Ambon dan Sumba yang saling bersaing. Kedua kelompok mahasiswa ini sendiri berada dalam kategori pertalian yang sama yaitu jika ditinjau dari sudut etnis. Keduanya menonjolkan identitas etnis mereka dalam memandang konflik individu ini sehingga muncul masalah antar kelompok. 
Terkait masalah etnik ini, mengacu pada Liliweri (2005:13), etnik atau kelompok etnik memiliki dua pengertian yaitu secara luas maupun sempit. Secara luas, etnik berkaitan dengan kehadiran suatu kelompok tertentu yang terikat dengan karakteristik tertentu, dari fisik, sosialbudaya, sampai ideologi. Sedangkan secara sempit, etnik etnik sering dikaitkan dengan konsep suku bangsa. Jadi, istilah kelompok etnik merupakan konsep untuk menerangkan suatu kelompok, baik kelompok ras maupun yang bukan kelompok ras, yang secara sosial dianggap berada dan telah mengembangkan subkultur sendiri.

Dengan memandang bahwa sebuah masalah dapat menjadi masalah kelompok maka dapat dikatakan bahwa etnisitas menjadi identitas utama bagi kelompok mahasiswa ini di atas identitas-identitas lain yang menyertai diri mereka. Sen (2006:45-46) sendiri menyebut bahwa terdapat dua pemikiran mengenai identitas utama atau dominan ini. Pada pendapat pertama disebut bahwa seseorang tidak memiliki akses ke konsepsi identitas lain yang terlepas dari komunitasnya, serta ke cara berpikir lain tentang identitas. Sedangkan pada alur pemikiran yang kedua, tidak disimpulkan bahwa keterbatasan tersebut merupakan kondisi terberi, tetapi mengklaim bahwa identitas merupakan persoalan penemuan semata, dan bahwa identitas komunitarian tak pelak lagi akan diakui sebagai yang terpenting bila kita diharuskan membuat perbandingan-perbandingan. Jika berkaca dari sejumlah kasus yang terjadi tersebut, kelompok mahasiswa asal Indonesia Timur di Kota Malang condong pada pendapat kedua dan menyebabkan identitas etnik di atas segalanya dan pada beberapa kasus menyeret identitas entik tersebut pada ranah pribadi mereka.

Menguatnya identitas etnik pada kelompok mahasiswa ini sendiri dapat diduga disebabkan karena kondisi mereka yang jauh dari kampung halaman dan berada pada kondisi minoritas. Situasi etnis mereka yang menjadi minoritas di tanah rantau menyebabkan mereka menjadi lebih bersatu dan menjadikan hal tersebut sebagai identitas utama mereka. Jongman dan Schmid (1994) menyebut bahwa sebuah kelompok minoritas mempunyai kesadaran kelompok yang kuat dalam rasa kesatuan.

Perasaan minoritas dalam bentuk etnik ini sendiri juga ditambah dengan kondisi terpinggirkan yang dimiliki oleh kelompok mahasiswa tersebut sebagai kelompok anak muda. White (2004:19) menjelaskan hal ini dan mengacu bahwa anak-anak muda serta kaum minoritas merupakan kelompok yang kerap kali dipinggirkan tersebut. Kerugian ganda yang mereka miliki ini kemudian mendorong identitas etnik dan kesukuan yang lebih kuat dan menyebabkan rentan terjadinya konflik dengan kelompok lain. 
Kresna Abdi Parela, Winin Maulidya Saffanah, Khairul Anwar

\section{SIMPULAN}

Berdasar data konflik mahasiswa asal Indonesia Timur di Kota Malang pada 2014-2018 ini diketahui bahwa tawuran antar suku merupakan salah satu konflik yang kerap terjadi dan bahkan hampir tiap tahun terjadi. Dua kelompok yang paling kerap berhadapan adalah kelompok mahasiswa asal Sumba dengan kelompok mahasiswa asal Ambon. Konflik yang terjadi ini sendiri kerap diawali oleh kesalahpahaman yang dipicu oleh minuman keras dan seringnya berakhir menjadi sebuah tawuran antar kelompok yang menimbulkan kerugian.

Solidaritas kelompok yang kuat pada hal ini kadang malah menimbulkan kerugian karena masalah yang sebenarnya sepele dan dapat ddiselesaikan secara kekeluargaan menjadi meruncing dan tak jarang harus diselesaikan melalui jalur hukum. Berkali-kali terlibatnya kelompok yang sama juga menandakan bahwa tidak adanya kesadaran dari kedua kelompok itu untuk saling menjaga anggotanya dan menahan diri dari konflik lebih lanjut yang dapat terjadi. Minuman keras sendiri merupakan pemantik awal pada sejumlah kasus tawuran dan setidaknya harus cukup diawasi konsumsinya oleh kelompok mahasiswa yang terlibat agar tidak terus menjadi penyebab konflik seperti yang sudah-sudah. Kendati demikian, menurunnya jumlah konflik yang terjadi terutama berupa tawuran antar kelompok etnik pada 2017 dan 2018 merupakan tanda bahwa kelompok yang sebelumnya bertikai sudah mampu setidaknya menahan diri untuk tidak membuat masalah yang ada ini jadi kian meluas.

\section{DAFTAR PUSTAKA}

A.J. Jongman dan A.P. Schmid. 1994. Monitoring Human Rights: Manual for Asessing Country Performance. Leiden, LISWO.

Isre, M. S. 2003. Konflik Etno Religius Indonesia Kontemporer. Jakarta: Departemen Agama R.I.

Liliweri, A. 2005. Prasangka \& Konflik; Komunikasi Lintas Budaya Masyarakat Multikultur. Yogyakarta: LKiS.

Sen, A. 2016. Kekerasan dan Identitas. Jakarta: Marjin Kiri.

White, Rob, et. al. 2014. Geng Remaja: Fenomena dan Tragedi Geng Remaja Dunia. Yogyakarta: Gala Ilmu Semesta.

Wirawan, B.I. 2012. Teori-Teori Sosial. Jakarta: Prenadamedia Group. 